\title{
Evaluation of Heartrot Caused Phellinus Pini and Related Yield Loss in Pinus Sylvestris Stands
}

\author{
Ziedonis Miklašēvičs \\ Rezekne Academy of Technologies. \\ Atbrīvošanas aleja 90, Rēzekne, \\ LV-4600, Latvia \\ z.miklasevics@lvm.lv
}

\begin{abstract}
Tree wounds are the starting points that may lead to heartwood discoloration and decay caused by invading micro-organisms such as heartrot caused Phellinus pini. Phellinus pini most frequently occurs on douglas-fir (Pseudotsuga menziesii), pine (Pinus sylvestris) and spruce trees (Picea abies). According to investigations made in this area, infection by Phellinus pini entries through felling scars or broken tops when Phellinus pini fruiting bodies (conks) on other trees are realising airbone spores. When spores land on a freshly wounded stem, the infection process starts.

Internal decay is often difficult to detect because only Phellinus pini conks indicate its presence. In most cases the number of conks doesn't exceed one-two pieces on the surface of inficied Pinus sylvestris stems. When wood poles for power lines are harvested in length from 10 to $16 \mathrm{~m}$ in wood felling areas where the average height of Pinus sylvestris trees is more than $27 \mathrm{~m}$, the local distribution of heartrot doesn't exceed for more than $1.5 \mathrm{~m}$ above and below each conk, the conk is located in the middle part of the pole length, the speeed of pruning exceeds $4 \mathrm{~m} / \mathrm{sek}$, the hight level of risk exists that the damaged with heart rot wood pole will be accepted as appropriate to quality requirements toward heartrot because after pruning the presence of conk would be vanished but the top and butt surfaces of pole's won't indicate heartrot. The evidence of heartrot will be checked only in the technological process of debarking before impregnation when Phellinus pini conk place indicates.

The purpose of this study is to predict the influence of Phellinus pini on Pinus sylvestris stems and to provide operational and safety recommendations concerning the risky assessment and management of infected felling areas in harvest planning processes.
\end{abstract}

Key words- Phellinus pini, Pinus sylvestris, wood poles for power lines

\section{INTRODUCTION}

Pinus sylvestris is the world's most widespread conifer after Juniperus communis. Its native range includes Albania, Andorra, Armenia, Austria, Azerbaijan, Belarus, Bosnia \& Herzegovina, Bulgaria, China, Croatia, Czech Republic, Estonia, Finland, France, Georgia, Germany, Greece, Hungary, Italy, Kazakhstan, Latvia, Lithuania, Macedonia, Mongolia, Montenegro, Norway, Poland, Portugal, Romania, Russia, Serbia, Slovakia, Slovenia, Spain, Sweden, Switzerland, Turkey, Ukraine, and the United Kingdom.[3].

Phellinus pini is one of the most common stem and butt decay fungi in conifers. According to investigations [1]; [10], its distribution spreads across the north temperature zone. Phellinus pini most frequently occurs on Douglas fir (Pseudotsuga menziesii), pine (Pinus sylvestris), spruce (Picea abies) and western larch (Larix occidentalis) [7].

Decay dynamics and damage will vary with host species and age [12]. According to literature data, the evaluation of Phellinus pini has not been studied extensively. Infection through adaxial twigs and branches usually occurs in late fall or early spring when the bark is loose. As the result it causes red ring rot. Developing of heartrot in hardwood can take over 100 years. The early stage of decay appears as a reddish-purple stain in the heartwood. During incipient decay the surrounding wood tends to be discoloured when the wood strenght parameters doesn't significantly changed [1], [10], [16]. Decay is usually confined to the heartwood of mature trees and the most extensive deccay occurs in the trunk [9]; [16]. Decay develops after Phellinus pini fungus causes the springwood. The fungi firstly destroying lignin and later cellulose [11]. From this stage fruiting bodies may develop at branch stubs or wound faces along the stem. The appearance of conks are usually brownish, hard, woody and hoof-shaped. According to investigation results [16] only Phellinus pini consistently produce the conks that indicate heartrot decay. 


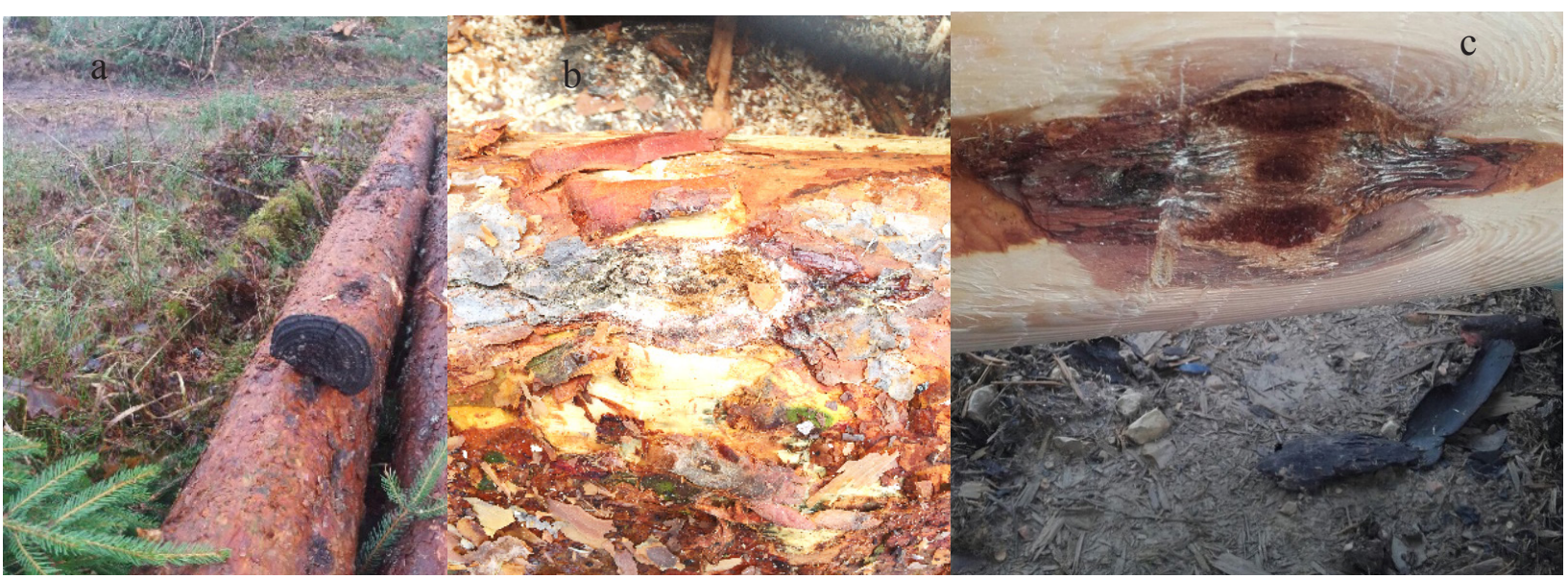

Fig. 1. Pinus sylvestris stem with heartrot indicator - Phellinus pini conk, where:

$\mathrm{a}$ - conk on the growing tree; b-conk place after harvesting; c-conk place after debarking

Pinus sylvestris separate the wound and subsequent decay by forming barrier zones of cells in the pholoem and xylem to prevent fungal spread. Therefore, the wound usually won't exceed the diameter of the tree at the time the damaging happened (Fig.2). Phellinus pini may overcame these barriers resulting in canker enlargement [6]. There is no approved information in literature if the amount of decay correlates with the wound size and age [18].

If the tree is unsuccessful to prevent fungal spread, decay will spread further into the heartwood. In trees with advanced decay conks are often seen along the lenght of the stem (Fig.1.)

According to investigation results [9], [14] Phellinus pini is one of the most descrustive heartrots in North America, especially in old growth forests [1]. According to investigation results [5] the average loss due to Phellinus pini decay is about $10 \%$ of the volume of interior stands, less than 5\% in stands on Vancouver Islans and the Queen Charlotte Islands and about $15 \%$ of the gross volume of Douglas fir stands western Oregon and Washington state. Unfortunately, the studies addressing Phellinus pini investigation is limited in Latvia [2], [3], [4], [13], [17], [19].

Therefore, the risk related to Phellinus pini is underestimated when harvesting is managed in old growth forests. The quality problems related to heartrot reveals in manufacturing process of wood poles for power lines in the technological stage of debarking when places of Phellinus pini conks reveal visible on wood poles surfaces (Fig.1).

The goal of this study was to evaluate and predict the effects of Phellinus pini infection on structural stability of wood poles for power lines. The following objectives were set to achieve the study goal:to verify the presence of Phellinus pini by laboratory analysing of wood samples from conks places;

- to correlate the presence of visible indicators-conks of infection by Phellinus pini to wood poles structural condition as extend of decay, observed average shell thickness, number of annual rings in sound shell zone, in barrier and hardwood zone, required shell thickness, etc;

- to collect and analyse all measurement results;
- to prepare the technological recomendations concerning risk assessment of felling areas infected by Phellinus pini in forestry operations

\section{MATERIALS AND METHODS}

A field study was carried out at the period May December of 2017, in Vidzeme region of Latvia and in energy company JSC "Sadales tīkli". Wood poles which were harvested in Vacciniosa and Myrtillosa forest types where the age of pine stands according to the forest inventory description was more than 105 years old were selected in the investigation. The quality control of each of selected 4863 pcs. wood poles was done in each stage of technological process in JSC "Sadales tīkli". Traceability of wood poles was ensured. In order to gather information about impact of Phellinus pini on wood pole's strenght parameters, the following approach, methods and data was collected:

- data characterized the wood felling area: coordinates of wood felling area; forest type;

- growing stock; growth conditions; site quality classes; species composition index and the age of species;

- data characterized the wood pole's visual quality parameters: lengh of wood pole; wood pole top and butt diameter; wood pole diameter at a conk positions; a conk possition measured from the wood pole butt and a conk location place dimensions on infected tree surface;

- data characterized wood pole's quality parameters at the position on the wood pole where Phellinus pini conk or blid conk was visible: number of annual rings in sound shell zone; number of annual rings in barrier and hardwood zone damaged by Phellinus pini; total number of annual rings; mean thickness of annual rings in sound shell zone; mean thickness of annual rings in barrier zone; mean distance of heart rot measured from conk position toward to wood pole butt; mean distance of heartrot measured from conk position toward to the wood pole top; mean distance of internal wood staining area (indicative of incipient decay) measured from conk position toward to the wood pole butt; mean distance of internal wood staining area (indicative of incipient decay) measured from conk position toward to the wood pole top; 
Required Shell Thickness; observed Average Shell Thickness and calculation of mean AST/RST ratious.

\section{RESULTS AND DISCUSSION}

When wood poles for power lines are harvested in length from 10 to $16 \mathrm{~m}$ in infected by Phellinus pini wood felling areas where the average height of pine trees is more than $27 \mathrm{~m}$, the conk is located in the middle part of the pole length, the speed of pruning exceeds $4 \mathrm{~m} / \mathrm{sek}$, the hight level of risk exists that the damaged with heartrot wood pole will be accepted as appropriate to quality requirements toward heartrot. After pruning the presence of conk would be vanished but the top and butt surfaces of pole's won't indicates heartrot. The evidence of heartrot will be checked only in the technological process of debarking before impregnation when Phellinus pini conk place indicates (Fig. 1)

For the long period, in the process of quality evaluation of wood poles before impregnation, the conk places were evaluated as the unspound knots. Only when the heartrot as a cause of breaking of wood poles was checked, the problem started to be explored.

For investigation of the reason of heartrot, the sample of damaged wood was taken and analysed (Fig.2) in the laboratory of molecural genetics LSFRI Silava.

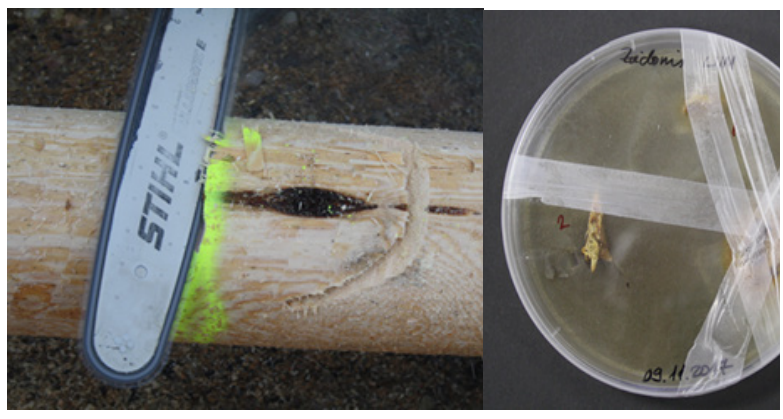

Fig. 2. The example of examined wood taken for molecural genetics analyse

The results of the laboratory analyses revealead the reason of heartrot in infected wood poles - Phellinus pini.

According to the investigation objective, the dimensions of Phellinus pini conk's location places were measured on infected wood poles surfaces (Fig.3). The measurement results are given in Table 1.

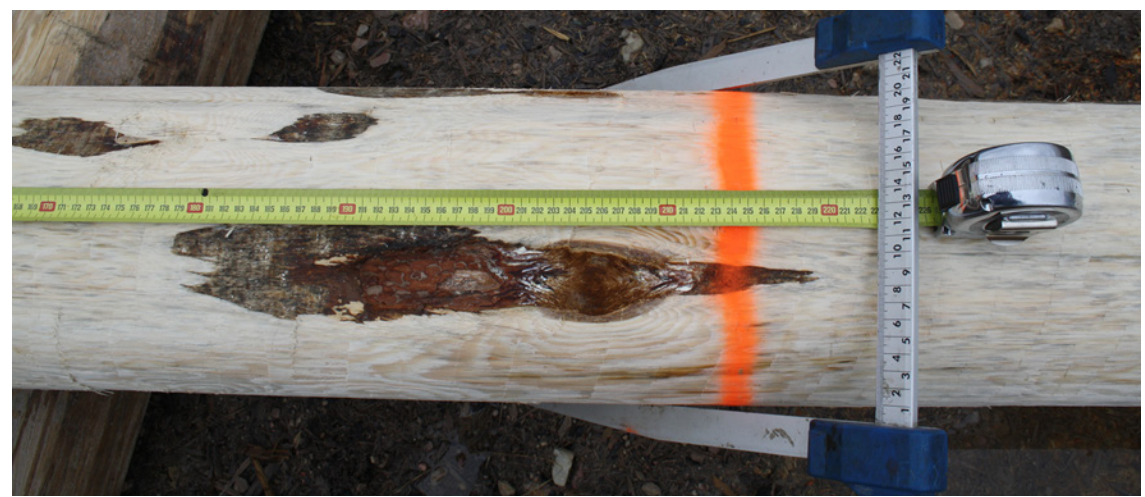

Fig. 3. The measurement of conk location place dimensions on infected wood pole surface

All wood poles on which surfaces were indicated Phellinus pini conk's were cross or/and longitudinally sectioned at the position of the visible conk's or blind conk's (Fig.4; Fig.5; Fig.6). In some cases wood poles

were cross sectioned above and below the conk's in order to evaluate AST at these positiions. The investigation results is given in Table1.
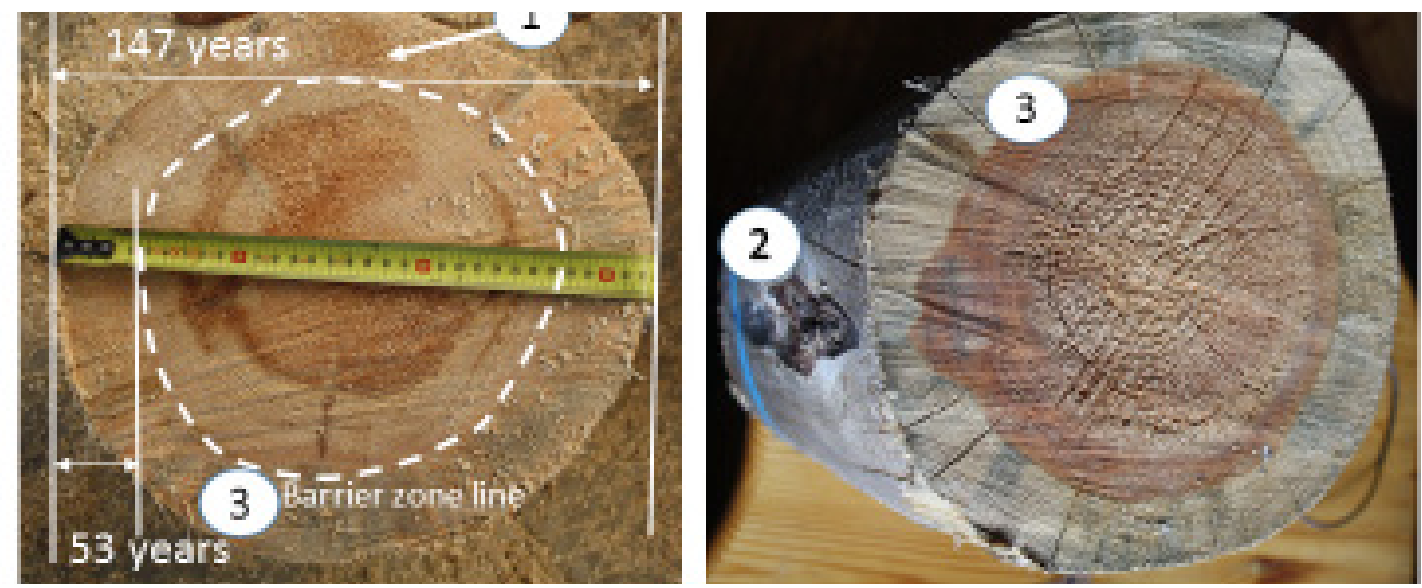

Fig. 4. Cross sections of infected Pine wood poles upper Phellinus pini conks possition where:

1 - entry point of fungus at old branch stub, 2- conk possition, 3- barrier zone line which indicates the outer limit that heart rot would have extended in this tree [15], [18] 

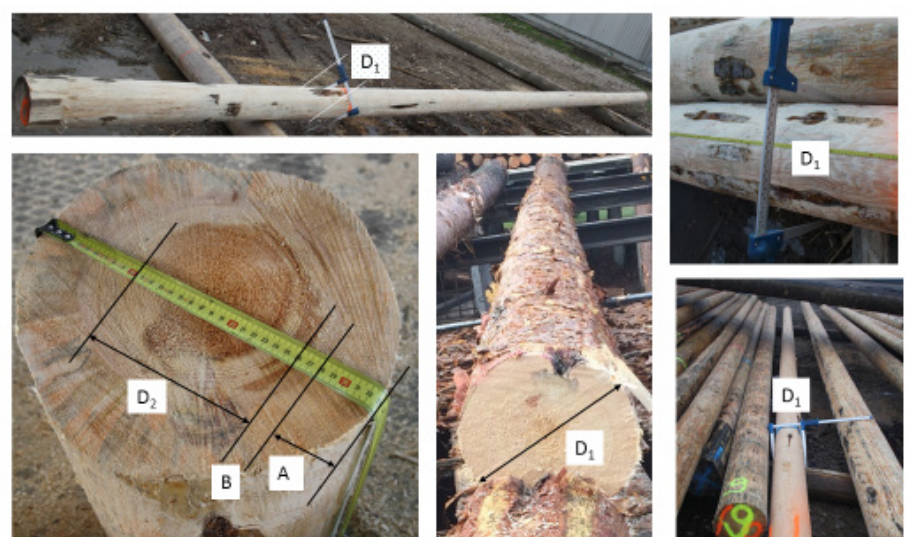

Fig. 5. The analyses example of cross section of infected pine wood pole taken at a conk position, where:

$\mathbf{D}_{1}$ - wood pole diameter at conk position, $\mathrm{mm} ; \mathbf{D}_{2}$ - diameter of hardwood damaged by Phellinus pini, $\mathrm{mm}$; B- number / thickness of annual rings in barrier zone, $\mathrm{mm}$; A- number / thickness) of annual rings in sound shell zone, $\mathrm{mm}$
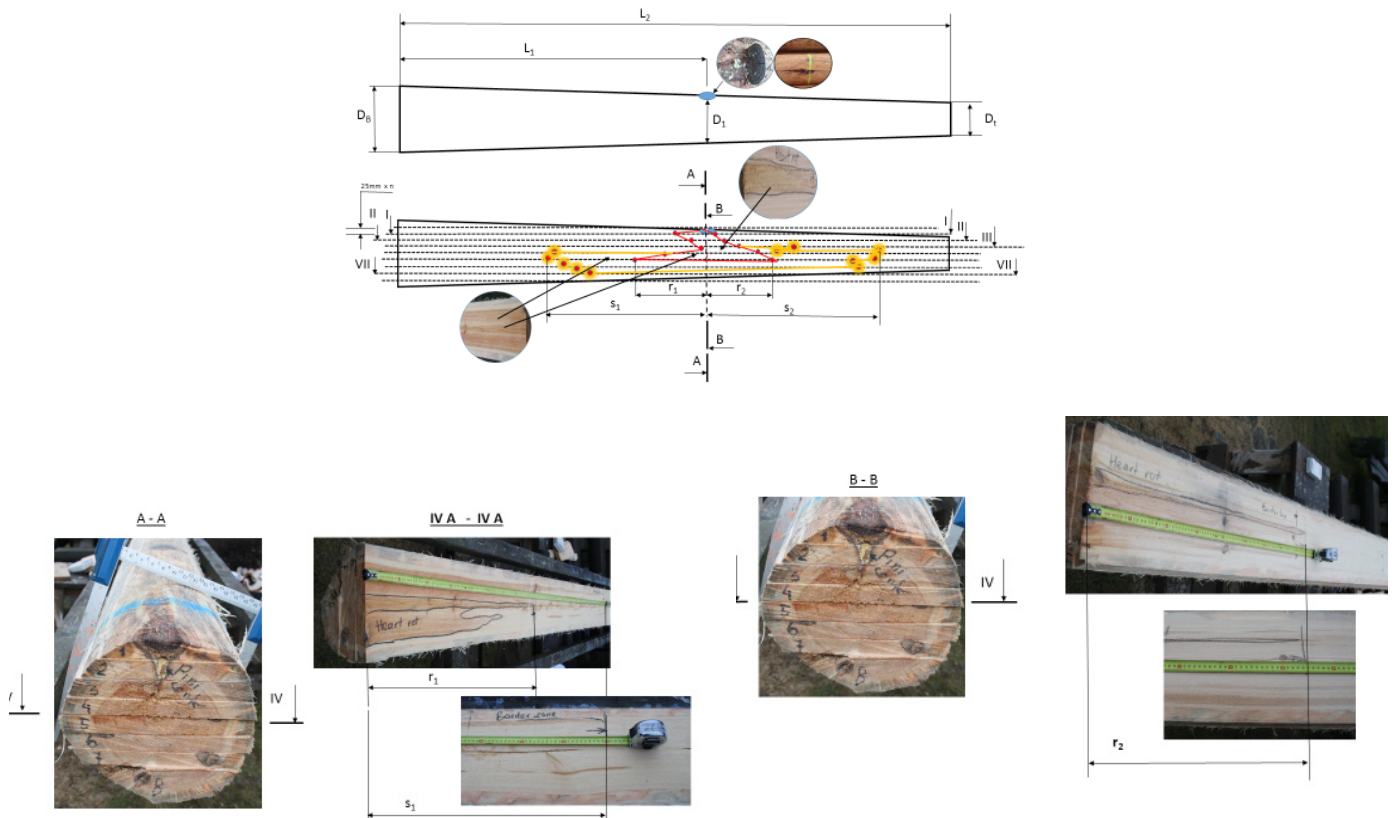

Fig. 6. The analyses example of longitudinal section of infected pine wood pole taken at conk position, where: $\mathrm{L}_{1}$ - distance of conk possition measured from butt, $\mathrm{cm} ; \mathrm{L}_{2}$ - lenght of wood pole, $\mathrm{cm} ; \mathrm{D}_{1}-$ wood pole diameter at conk positions, mm; $\mathrm{r}_{1}$ - distance of heart rot measured from conk position toward to wood pole butt, $\mathrm{mm} ; \mathrm{r}_{2}$ - distance of heart rot measured from conk position toward to wood pole top, $\mathrm{mm}$; $\mathrm{s}_{1}$ - distance of wood staining (indicative of incipient decay) measured from conk position toward to wood pole butt, $\mathrm{mm}$; $\mathrm{s}_{2}$ - distance of wood staining (indicative of incipient decay) measured from conk position toward to wood pole top, $\mathrm{mm}$

TABLE 1. THE MEASUREMENT RESULTS CHARACTERIZED DAMAGES OF PINE WOOD CAUSED BY PHELLINUS PINI

\begin{tabular}{|c|c|}
\hline Mean conk location place dimensions on infected tree surface, $\mathrm{cm}^{2}(\mathrm{n}=128)$ & 24.8 (range 16.3 \\
$-28.7)$
\end{tabular}




\begin{tabular}{|c|c|}
\hline $\begin{array}{l}\text { Mean AST*, mm }(\mathrm{n}=128) \\
\text { AST - observed Average Shell Thickness. Calculated as the average of actual wood } \\
\text { pole sound shell width measured at } 3 \text { points around the pole at a given height position. } \\
\text { This positrion corresponds to the position of the defect indicator (i.e.,conk) above pole } \\
\text { height }\end{array}$ & $\begin{array}{l}35.4( \pm \text { SD 5.22) } \\
\quad( \pm \text { SE } 0.46)\end{array}$ \\
\hline $\begin{array}{c}\text { Mean } \mathrm{RST}^{*}, \mathrm{~mm}(\mathrm{n}=128) \\
\boldsymbol{R S T} \text { - Required Shell thickness. Calculated as a wood pole radius at a conk position }\left(D_{l}\right. \\
\text { /2) } x 0.30 \text { (Fig.5.) }\end{array}$ & $\begin{array}{l}30.2( \pm \text { SD } 9.44) \\
\quad( \pm \text { SE } 0.83)\end{array}$ \\
\hline $\begin{array}{l}\text { Overall Mean AST/RST * ratio /(n=128) } \\
\text { An AST/RST ratio of } 1.00 \text { or grater means that the actulal average stem shell thickness is } \\
\text { equal to the required minimum of shell thickness and soundwoood shell ensures columnar } \\
\text { strenght and structural stability. When ratio AST/RST }<1.00 \text {, wood pole have relatively } \\
\text { thin stem shell walls and therefore have insufficient sound stemwood shell to maintain } \\
\text { columnar strenght and structural stability. }\end{array}$ & $\begin{array}{l}0.81( \pm \text { SD 0.22) } \\
\quad( \pm \text { SE } 0.019)\end{array}$ \\
\hline Mean AST/RST ratio of wood poles with blind conks ( $\mathrm{n}=4,4$ wood poles) & 1.86 \\
\hline Mean AST/RST ratio of wood poles with multiple conks ( $\mathrm{n}=14,4$ wood poles) & 0.72 \\
\hline $\begin{array}{l}\text { Mean distance of heart rot measured from conk position toward to wood pole butt, } \mathrm{mm} \\
\text { (59 wood poles) }\end{array}$ & $\begin{array}{l}875( \pm \text { SD 185.43) } \\
\quad( \pm \text { SE 24.14) }\end{array}$ \\
\hline $\begin{array}{l}\text { Mean distance of heart rot measured from conk position toward to wood pole top, } \mathrm{mm} \\
\text { (65 wood poles) }\end{array}$ & $\begin{array}{l}850( \pm \text { SD } 176.31) \\
\quad( \pm \text { SE } 21.87)\end{array}$ \\
\hline $\begin{array}{l}\text { Mean distance of internal wood staining area (indicative of incipient decay) measured } \\
\text { from conk position toward to wood pole butt, } \mathrm{mm} \text { ( } 43 \text { wood poles) }\end{array}$ & 2370 \\
\hline $\begin{array}{l}\text { Mean distance of internal wood stain } \\
\text { from conk position toward to wood po }\end{array}$ & 2240 \\
\hline
\end{tabular}

\section{CONCLUSIONS}

The results of the study indicated the following:

- About $1.5 \%$ of inspected 4863 pcs wood poles harvested in felling areas in Vacciniosa and Myrtillosa forest types where the mean age of pine trees were 111 years old were infected by Phellinus pini.

- Wood poles for power lines are building structure which characterize strenght parameters. Typical minimum characteristic values for Pinus sylvestris wood poles by standard EN 14229 are: bending strenght $\mathrm{f}_{\mathrm{m}}=48.97 \mathrm{~N} / \mathrm{mm}^{2}$; modulus of elasticity $\mathrm{E}=8000 \mathrm{~N} / \mathrm{mm}^{2}$ [17], [21].

Wood poles strenght parametrs mainly dependent of wood density. When wood pole's structural stability is being impacted by heartrot caused by Phellinus pini when Overall Mean AST/RST $<1$, the expluatation risky will be actual because of low parametrs toward bending limit and modulus of elasticity.

- There are advisable to evaluate the pine trees external quality before harvesting of wood poles for power lines inVidzeme region of Latvia in felling areas in Vacciniosa and Myrtillosa forest types where the age of pine stands is more than 100 years old (Fig.7). In cases when the Phellinus pini are being indicated, wood pole's should be harvested using motor saws.

To eliminate expluatation risky of wood poles for power lines, new information related to infected by Phellinus pini felling areas is required for harvesting planning.

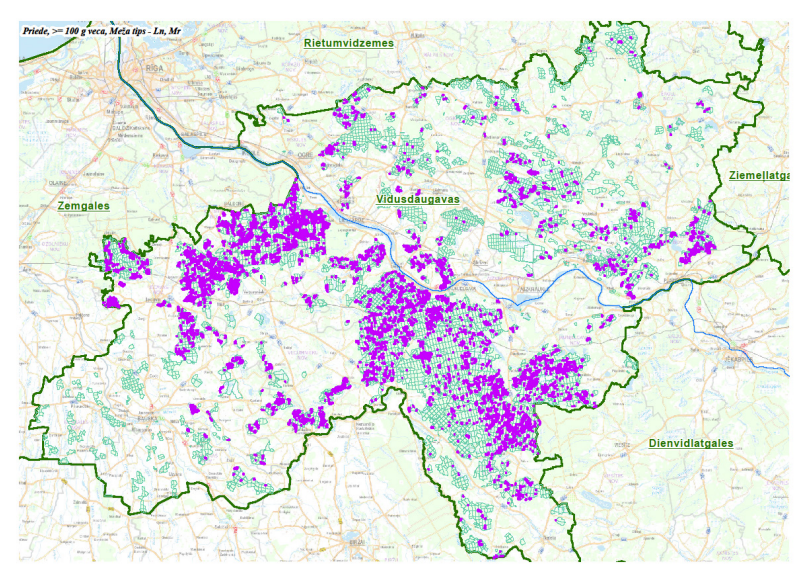

Fig. 7. The felling areas in Vacciniosa and Myrtillosa forest types in Vidzeme region of Latvia

where the age of pine trees is more than 100 years old

\section{REFERENCES}

[1]. Conference paper-Allen E., Morrison D., Wallis G., 1996. Common Tree Diseases of British Columbia 178p. [Online]. Available: https://www.pfc.forestry.ca/diseases/CTD/index_e.html.

[2]. Journal: Arhipova N., Gaitnieks T., Donis J., Stenlid J., Vasaitis R., 2011. Butt rot incidence, causal fungi and related yield loss in Picea abies stands of Latvia. Canadian Journal of Forest Research, 41(12), pp.2337-2345

[3].Journal: Baumanis I., 1993. A complex research project: factors in Latvia affecting the health of pine (planting stock and young plantations), and recommended protective measures. Proceedings of the Latvian Academy of Sciences, Section B, 7(552), pp. 79-80.

[4]. Book: Baumanis I., Jansons, Ā., Neimane U., 2014. Selection, genetics and seeding in Latvia. In: Daugavpils, 324 p.

[5]. Journal: Bier, J.E., R.E. Foster and P.J. Salisbury. 1946. Studies in forest pathology. IV. Decay of Sitka spruce on the Queen Charlotte 
Islands. Can. Dept. Agric. Publ. 783. Tech. Bull. \#56. 35 pp.

[6]. Journal: Blanchette R.A., 1982. Decay and canker formation by Phellinus pini in white and balsam fir. Can. J. For. Res. 12: pp. 538544.

[7]. Book: Boyce, J.S. 1961. Forest Pathology. 3rd. Ed., McGraw-Hill, Toronto.

[8]. Journal: Earle C.J., 2011. Pinus sylvestris (Scots pine) description. In: The Gymnosperm Databaswe. [WWWdokument]. [Online]. Available: http://www.conifers.org/pi/Pinus sylvestris.php [archived in July, 2014]

[9]. Journal: Etheridge D.E.,1972. True heartrots of British Columbia. Canadian Forest Service, Pacific Forest Research Center, Victoria, BC.Forest Pest Leaflet No. $55.14 \mathrm{p}$.

[10]. Journal: Hunt R.S., Etheridge D.E., 1995. True heart-rots of the Pacific Region. Forest Pest Leaflet No.55, Pacific Forestry Centre. $8 \mathrm{p}$.

[11]. Journal: Kimmey J.W., 1964. Heart rots of Western Hemlock. Forest Pest Leaflet 90, U.S. Dep't of Agriculture. Accessed 5 Mar. 2007. [Online]. Available: https://www.fs.fed.us/r10/spf/fhp/ leaflets/Hearotweshem.htm

[12]. Journal: Larsen M.J., Lombard F.F., 1979. A new variety of Phellinus pini associated with cankers and decay in white firs in southwestern Oregon and northern California. Can. J. For. Res. 9: pp.31-38.

[13]. Journal:Līibiete Z., Jansons J., Zālīitis T., 2009. Age structure and productivity of conifer stands in Latvia. Mežzinātne / Forest Science 19(52): pp.28-48.
[14]. Book: Scharpf R.F., 1993. Diseases of Pacific Coast Conifers. USDA For. Service, Pacific Southwest Research Station, Albany, CA. USDA For. Serv. Handbook 521, June 1993. 199 p.

[15]. Book: Shigo A.L., 1991. Modern Arboriculture. Shigo and Trees, Associates, Durham, NH. 424 p.

[16]. Conference paper - Zeglen S., 1997. Tree wounding and partial-cut harvesting: A literature review for British Columbia. BC Min. Forests Pest Management Report No. 14, Vancouver Forest Region, Nanaimo, BC. 40 p.

[17]. The technological investigations and ecological evaluation of manufacturing of wood poles for power lines.[Online]. Available: https:// llufb.llu.lv/dissertation-summary/engineering/Z Miklasevics l-a.pdf

[18]. Evaluation of the effects of heart rot fungi on live tree structural stability. [Online]. Available: https://www.for.gov.bc.ca/.../ WTReport-Effects-of-HeartRotFungi-June. [Accessed 2007].

[19]. Assessment of the development of the forest industry https://www.zm.gov.lv/public/ck/files/ZM/mezhi/.../1_pielikums.pdf. [Accessed 2011]

[20].. Opinin on the draft guidelines on forest and related development guidelines for 2015-2020. Available: VSS-489 ldf.lv/sites/ default/files/faili/Par_mums/LDF_vestules/80_ldf_msnp_vss 489 . doc

[21]. EN 14229. Structural timber-Wood poles for overhead lines 